\title{
Composition and diversity of the fish assemblages under influence of a gradient river/dam of Taquari River, São Paulo, Brazil
}

\author{
J. Queiroz ${ }^{1}$, H. Brandão ${ }^{1}$, S. Britto ${ }^{1}$, A. B. Nobile ${ }^{1} \&$ R. J. Silva ${ }^{2}$ \\ ${ }^{I}$ Department of Morphology, Institute of Biosciences, \\ UNESP - University of São Paulo State, Botucatu, Brazil \\ ${ }^{2}$ Department of Parasitology, Institute of Biosciences, \\ UNESP - University of São Paulo State, Botucatu, Brazil
}

\begin{abstract}
The structure of ichthyofauna is determined by several factors involving environmental characteristics that modify along the gradient river dam. The aim of this study was to compare the ichthyofauna distribution of a subtropical dam tributary in four distinct stretches along the river/dam gradient. The samples were carried out quarterly during a year using gill nets, trawling, and sieves with a standardized capture effort to capture fish. The ichthyofauna of the tributary presented 41 species with 4,598 individuals. Three non-native species were recorded. The richness of species did not show significant difference among the stretches, although Shannon-Wiener diversity and evenness showed significant variations among the stretches. The distribution ordination (partial CCA) showed greater correlation between fish assemblage and impacted composition of surroundings. This study approaches the existence of an environmental gradient within the river mouth, influenced by a reservoir and the variations of the fish assemblage.
\end{abstract}

Keywords: ecological attributes, teleost, environmental gradient, reservoir.

\section{Introduction}

The spatial distribution of fish assemblages on a river/dam gradient is influenced by the heterogeneity of environmental physiography, the behavioral characteristics of the intra and inter-specific interactions, and environmental 
conditions [1]. The limnological and structural characteristics of habitat are considered the main responsible for differences in the structure of the fish assemblages in the diverse types of environment in a same aquatic ecosystem or biogeographical region $[2,3]$. Communities that show non-random distribution are submitted to the action of at least one structuring factor, which might be an environmental gradient $[4,5]$. It establishes spatial patterns of fish assemblages and their relation with environment [6].

According to the "River Continuum Concept" by Vannote et al. [7], which presents those patterns, large rivers might hold greater species abundance than their tributaries of inferior order or even medium rivers. These showed more local effects depending on the volume and the nature of the allochthonous matter input [8]. However, this concept does not apply for rivers whose local effects are subjected to disturbances; for instance, dammed rivers in which the discharge is regulated according to the production of hydroelectric energy to attend the society needs. River damming has been considered one of the most disturbing actions upon river systems [9].

Other anthropic activities are also responsible for disturbances, such as agriculture, livestock, and urbanization [10]. In the Southeast of Brazil, the deforestation has already destroyed $75 \%$ of the riparian forest [11]. The transformation from riparian forest to farmland influences the availability of aquatic microhabitats for resident fishes [12]. Besides, the introduction of nonnative fish species increases the possibility of promoting changes in the fish population structure, including the disappearance of sensible species even before being known by science [13].

Studies that approach the composition and diversity of fish assemblages along the environmental gradient of water bodies contribute to the understanding of the anthropic actions effects regarding management and selection of conservation areas [10]. Such studies also apply as models to evaluate the use of complex habits, for example in conservation biology of aquatic environments [3], and to detect degraded ecosystems in order to suggest improvements [14]. The Taquari River, São Paulo State, Brazil, which was selected to conduct this study, shows surrounding areas relatively preserved, but also areas impacted by high tech agriculture. This situation leads us to the following question: Are the fish assemblages distinct in different stretches along the river/dam gradient of this river? Considering the spatial distribution of fishes in a river, the following hypothesis was tested: the diversity patterns are consistent with the river-dam gradient, considering anthropic interferences as cause of loss diversity in fish assemblages.

Thus, the aim of this study was to compare the spatial distribution of the composition and ecological attributes of the ichthyofauna in four stretches along the river/dam gradient of the Taquari River. 


\section{Material and methods}

\subsection{Study area}

The Taquari River is one of the main tributaries of Jurumirim dam [15], in the left bank of the Upper Paranapanema River, located in the Southwest of São Paulo State, Brazil. Hydroelectric power plant operational system of Jurumirim dam affects the water level [16]. The surrounding landscape presents high tech agriculture with large areas of beans, corn and sugarcane fields, and also livestock activities [17].

In this study, the fish samplings were carried out in four stretches representing the distinct compartments of the river/dam gradient: Lotic/Upper $\left(23^{\circ} 40^{\prime} 2.90^{\prime \prime} \mathrm{S}\right.$;

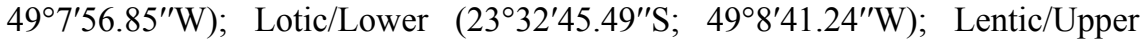
$\left(23^{\circ} 29^{\prime} 21.95^{\prime \prime} \mathrm{S} ; 4^{\circ} 12^{\prime} 6.90^{\prime \prime} \mathrm{W}\right)$; Lentic/Lower $\left(23^{\circ} 17^{\prime} 2.80^{\prime \prime} \mathrm{S} ; 49^{\circ} 12^{\prime} 6.90^{\prime \prime} \mathrm{W}\right)$ (Fig. 1).

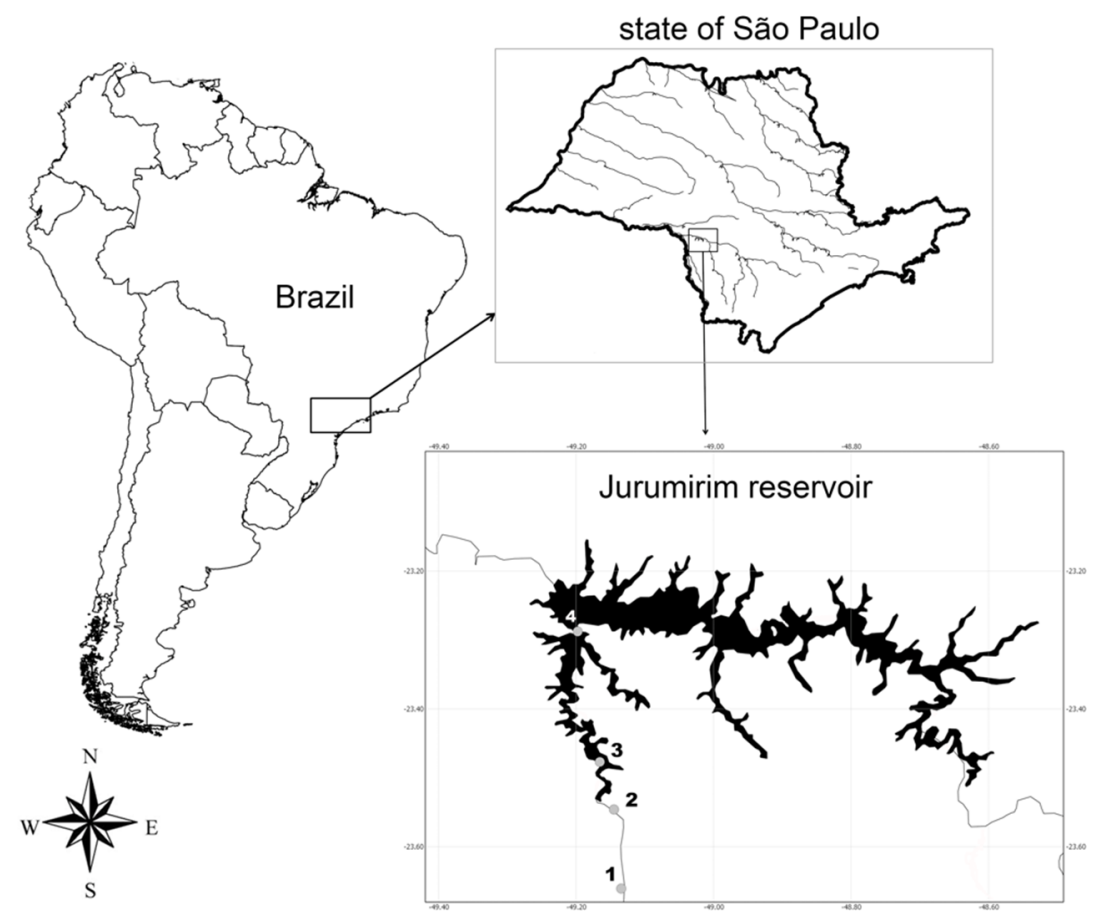

Figure 1: Map of the Taquari River, tributary of Jurumirim dam, São Paulo, Brazil. Stretches: 1: Lentic/Upper; 2: Lotic/Lower; 3: Lotic/Upper; 4: Lentic/Lower. 


\subsection{Sampling procedure}

The samplings were carried out every three months from April 2011 to January 2012 , using sieves $(1.5 \times 1 \mathrm{~m}-6$ times $)$, trawl nets $(10 \times 2 \mathrm{~m}$ with meshes of $5 \mathrm{~mm}-6$ times), and gillnets ( 3 to $14 \mathrm{~cm}$ mesh between opposite knots, exposed for 18 hours, checked once a day). Every fishing gear was used with standardized effort for each sampling stretch. Considering the sampling selectivity, the analyses of abundance and ecological attributes were applied only for individuals from gillnets. However, the characterization of composition was complemented with the data from other fishing gear.

\subsection{Laboratory procedure}

The fish samples were identified and measured: 1) Standard length in centimeters $\left(\mathrm{L}_{\mathrm{s}}\right)$; and 2) total weight in grams $\left(\mathrm{W}_{\mathrm{t}}\right)$. Voucher specimens were deposited in the "Coleção do Laboratório de Biologia e Genética de Peixes, Departamento de Morfologia, Instituto de Biociências da UNESP, campus de Botucatu, Brazil", a fish collection.

\subsection{Environmental variables sampling}

The following abiotic variables were measured in order to demonstrate possible variations among the stretches studied: a) water temperature, $\mathrm{pH}$, electrical conductivity, and dissolved oxygen, using the Multiparametric probe HORIBA U-50 in each stretch with maximum depth of 1 meter; b) water transparency using the Secchi disk; c) chlorophyll- $a$ by water filtration, using glass fiber filters Millipore AP40 for extraction of pigment in $90 \%$ acetone, d) sediment collected with a Van Veen grab with a sample of the material immediately frozen for subsequent analysis of total nitrogen and phosphorous; e) remaining sediment used for granulometry and determination of organic matter (weight loss by ignition); f) percentage of riparian forest, abandoned, agricultural and pasture areas to demonstrate the composition of the surroundings.

\subsection{Statistical analyses}

For the analysis of ichthyofaunistic data, the species richness using number of species; number of individuals; Shannon-Wiener diversity index: $\left(\mathrm{H}^{\prime}=-\sum\right.$ (pi.In pi)), in which $\mathrm{H}^{\prime}=$ species diversity, $\mathrm{pi}=$ proportion of species $\mathrm{i}$ in the community, in which $\mathrm{pi}=(\mathrm{ni} / \mathrm{N}) ; \mathrm{ni}=$ number of individuals of species $\mathrm{i}, \mathrm{N}=$ total number of individuals [18]; and Pielou evenness according to the formula: $\left(J^{\prime}=H^{\prime} / \log _{2} S\right)$, in which $J^{\prime}=$ evenness (varying from 0 to 1$)$ [18] were calculated.

Relations between environmental variables and community species composition were explored using method of Partial Canonical Correspondence Analysis (pCCA). The analyses were carried out with the CCA function of the "vegan" package [19]. Rare species generate a great number of null values impairing the establishment of biological associations. Thus, these species were 
eliminated in the ordination [20]. The species matrix was composited by 19 species in 11 samplings, the environmental matrix was composited by nine numeric variables (abiotic factors) and one categorical variable (month) in 11 samplings. Categorical variable was used as terms that are partialled out from the analysis before constraints. All numeric variables were transformed to $\log (x+2)$. The "vif.cca" function in R program was used to detect collinearity between environmental variables. Values over 10 indicate redundant constraints and thus were removed. Significance of pCCA was assessed by ANOVA as a permutation test.

To quantify the variation of the response data explained by a subset of explanatory variables when controlling for other subsets of explanatory variables, we used RDA as proposed by Borcard et al. [21] as a procedure of variation partitioning. The analyses were conducted with the function varpart in the "vegan" package [19]. This method recommends use of a model in which fish species were dependent data and other arguments give the sources of variation (environmental). Three subsets of environmental variables were created: (A) Water abiotic factors (B) Sediment and (C) Surroundings. Each subsets corresponded one-sided model formula: $(\mathrm{A})=\mathrm{Wt}+\mathrm{pH}+\mathrm{EC}+\mathrm{Chla}$, (B) $=\mathrm{CS}+\mathrm{OM},(\mathrm{C})=$ Forest + Agric . The data set with normal distribution we applied parametric tests (Anova). Every data was analyzed at the significance level $(\mathrm{p}=0.05)$.

\section{Results}

\subsection{Ichthyofauna}

A total of 4,598 fish individuals were collected, belonging to five orders, 16 families, 31 genus, and 41 species, considering the samplings from the three fishing gear (gillnets, trawl nets, and sieve) during the study period. From gillnets, 30 fish species were recorded. The non-native species Cichla kelberi, Oreochromis niloticus and Tilapia rendalli were recorded in the stretches Lotic/Lower, Lentic/Upper and Lentic/Lower.

\subsection{Spatial distribution and ecological indexes}

Cyphocharax modestus in the stretches Lotic/Upper and Lentic/Upper (Table 1) affected the pattern of richness and evenness (Table 2). Without the first dominant species, the pattern of the relative abundance for lentic/upper and lotic/lower were very similar.

The richness of species did not show significant difference among the stretches (ANOVA one way: $p=0.88$ ), but Shannon-Wiener diversity and evenness did (ANOVA one way: $p=0.045$ and ANOVA one way: $p=0.0047$, respectively). The greatest value of Shannon-Wiener diversity was observed for the Lotic/Lower stretch (2.67) and the smallest value for the Lentic/Upper (1.57). Regarding the evenness (E), Lotic/Lower showed the greatest value, followed by Lotic/Upper, and the smallest value was for Lentic/Upper (Table 2). 
Table 1: Importance order of the species, number of individuals (n) and biomass (B) in grams ( $\mathrm{g}$ ) of the fishes from the Taquari River, tributary of Jurumirim dam, Upper Paranapanema River, São Paulo State, Brazil, captured with gillnets.

\begin{tabular}{|c|c|c|c|c|c|c|c|c|}
\hline & \multicolumn{2}{|c|}{ Lotic/Upper } & \multicolumn{2}{|c|}{ Lotic/Lower } & \multicolumn{2}{|c|}{ Lentic/Upper } & \multicolumn{2}{|c|}{ Lentic/Lower } \\
\hline & & n & & n & & $\mathbf{n}$ & & $\mathbf{n}$ \\
\hline 1 & Cmod & 72 & Hanc & 44 & Cmod & 547 & Afas & 126 \\
\hline 2 & Sins & 53 & Hreg & 42 & Snas & 57 & Smac & 101 \\
\hline 3 & Hanc & 52 & Hlit & 32 & Smac & 45 & $I l a b$ & 57 \\
\hline 4 & Afas & 42 & Snas & 27 & Hlit & 33 & Snas & 52 \\
\hline 5 & Aalt & 19 & Aalt & 22 & Opar & 28 & Aalt & 24 \\
\hline 6 & Shil & 17 & Rque & 16 & $I l a b$ & 18 & Pmac & 17 \\
\hline 7 & Hmal & 16 & Pmac & 14 & Hreg & 17 & Opar & 16 \\
\hline 8 & Smac & 14 & Opar & 13 & Sins & 16 & Gkne & 12 \\
\hline 9 & Gkne & 13 & Smac & 13 & Hmal & 15 & Lelo & 10 \\
\hline 10 & Hreg & 9 & Rdor & 10 & Gsyl & 12 & Plin & 8 \\
\hline 11 & Pmac & 8 & Pava & 9 & Afas & 11 & Sins & 8 \\
\hline 12 & Plin & 6 & Afas & 8 & Lfri & 11 & Aaff & 6 \\
\hline 13 & Hlit & 6 & Shil & 8 & Pmac & 10 & Hmal & 3 \\
\hline 14 & Lstr & 5 & Sins & 7 & Shil & 8 & Shil & 2 \\
\hline 15 & Rque & 5 & Cmod & 6 & Rque & 8 & Ckel & 2 \\
\hline 16 & Lfri & 4 & Locto & 3 & Aalt & 4 & Hreg & 2 \\
\hline 17 & Locto & 3 & Gkne & 2 & Hanc & 3 & Pava & 2 \\
\hline 18 & Snas & 3 & Lstri & 2 & Gkne & 2 & - & - \\
\hline 19 & Pava & 3 & Plin & 2 & Pava & 2 & - & - \\
\hline 20 & Etri & 2 & $I l a b$ & 2 & Lelo & 1 & - & - \\
\hline 21 & Opar & 1 & Lelo & 1 & - & - & - & - \\
\hline 22 & Sint & 1 & - & - & - & - & - & - \\
\hline Total & & 354 & & 283 & & 848 & & 448 \\
\hline
\end{tabular}

The first two axes of the ordination explained $55.6 \%$ of the variation in the fish assemblage (CCA $1=31.0 \%$ and CCA $2=24.6 \%$ ). To CCA 1 , higher percentages of forest in surroundings, $\mathrm{Wt}, \mathrm{EC}$ and Chla were negatively correlated with fish composition of B2, D1, D2, D4. To CCA 2, higher percentages of $\mathrm{OM}$ and $\mathrm{CS}$ negatively and positively respectively correlated with fish composition of C1, C2, C4, D1, D2 and D4 (lentic stretches) (Figure 2). Permute test showed significance $(\mathrm{p}$-value $=0.003)$. The ordination among the 
Table 2: Ecological attributes of the fish assemblages by sampling stretches of the Taquari River, tributary of Jurumirim dam, Upper Paranapanema River, São Paulo State, Brazil.

\begin{tabular}{lcccc}
\hline $\begin{array}{c}\text { Ecological } \\
\text { Attributes }\end{array}$ & $\begin{array}{c}\text { Lotic/ } \\
\text { Upper }\end{array}$ & $\begin{array}{c}\text { Lotic/ } \\
\text { Lower }\end{array}$ & $\begin{array}{c}\text { Lentic/ } \\
\text { Upper }\end{array}$ & $\begin{array}{c}\text { Lentic/ } \\
\text { Lower }\end{array}$ \\
\hline Number of species & 22 & 21 & 20 & 18 \\
Shannon-Wiener & 2.53 & $2.67^{*}$ & $1.58^{*}$ & 2.16 \\
Evenness (E) & 0.77 & 0.81 & $0.48^{*}$ & 0.66 \\
\hline
\end{tabular}

(*) ANOVA p-value $<0.05$.

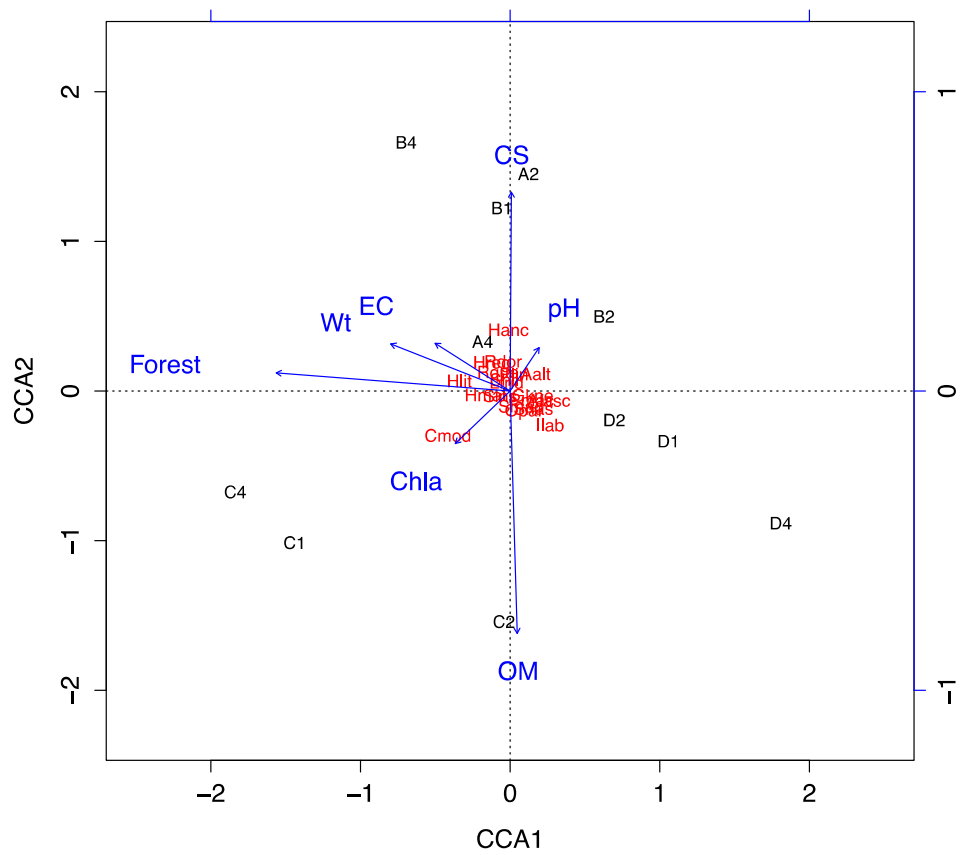

Figure 2: Ordination diagram made by the partial canonic correspondence analysis. Red: species in acronym. Descriptors group of stretches and species related to greater water transparency. Arrows: vectors of environmental variables: Chla - Chlorophyll $a(\mu \mathrm{g} / \mathrm{L}), \mathrm{CS}-$ coarse sand $(\%)$, EC - electrical conductivity $(\mu \mathrm{S} / \mathrm{cm})$, FOREST - Forest fragment $(\%), \mathrm{pH}, \mathrm{OM}-$ organic matter $(\%), \mathrm{Wt}-$ water temperature $\left({ }^{\circ} \mathrm{C}\right)$; black: sites: A - Lotic/Upper; B - Lentic/Upper; C - Lotic/Lower; D - Lentic/Lower.

sampling stretches indicated two distinct compositions of fish species due to influence of the river/dam gradient.

In the variation partitioning, individual fractions of Composition of the surroundings (c), water abiotic factors (a) and sediment (b) explained 26\%, 22\% and $12 \%$ of the variance in the fish assemblage according to the RDA analysis $\%$ 
respectively (Fig. 3). The shared variance between the surroundings and sediment was $4 \%$.

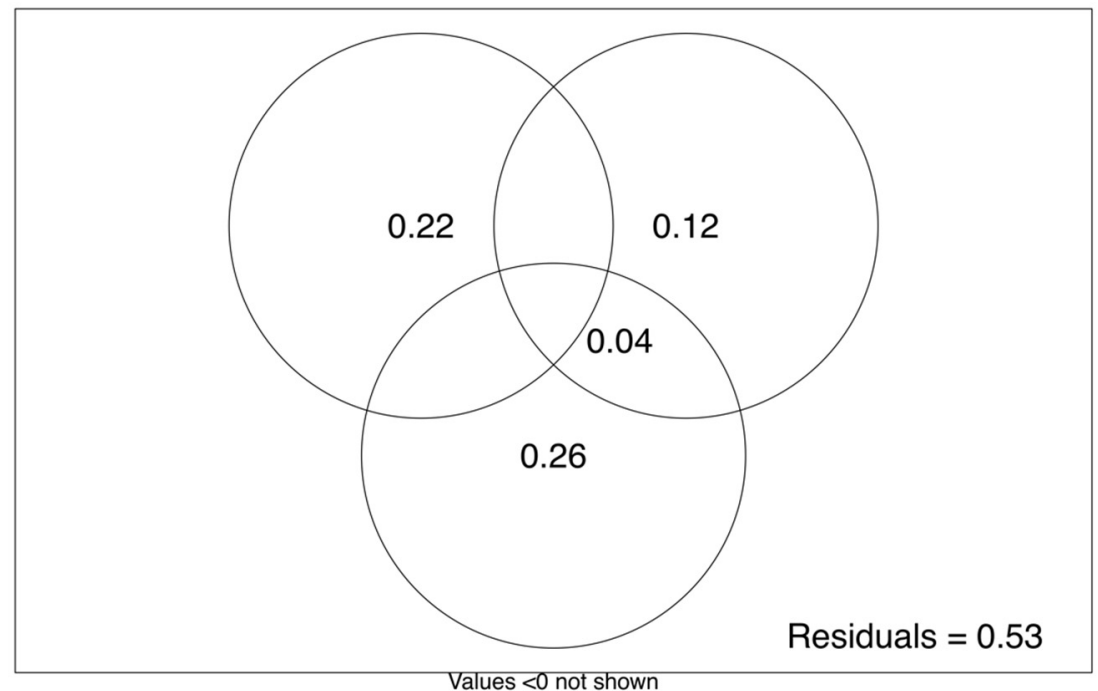

Figure 3: Results of the variance partitioning analysis. The contribution of each explanatory variable group is reported as variance in freshwater fish assemblage composition. (A) Water abiotic factors; (B) sediment; and (C) surroundings. The statistical significances of the fractions (after permutation tests) are: $*=p<0.05$.

\section{Discussion}

Our results indicate differences in the structure of the fish assemblages along the river/dam gradient. The distribution pattern studied did not follow River Continuum Concept, since the number of species and abundance decreased along the river/dam gradient of the river. The greatest values were recorded in the Lotic/Upper and Lotic/Lower stretches. Rivers have remaining species that do not inhabit reservoirs [22].

The greatest abundance and biomass of non-native fishes occurred in the stretch Lentic/Lower, represented by $C$. kelberi that was the only non-native species caught in gillnets. The dispersion source of non-native species occurs by accidental escape of farmed species from cage fish farms, by restocking programs, or even by species introduction [23] restricted to dammed sites.

Three long distance migratory species were recorded: Leporinus, P. lineatus and Salminus hilarii. They possibly used the Taquari River for reproduction and spawning, making it an important ecosystem for the conservation of remaining migratory species. Migratory species of large rivers generally show their stocks 
reduced or do not survive in dammed sites, since they need long distances to complete their reproductive cycle.

The occurrence of 12 short distance migratory species is observed and included Astyanax altiparanae, Astyanax fasciatus, Galeocharax knerii, Hypostomus reganii, Iheringichthys labrosus, L. friderici, Leporinus octofasciatus, Leporinus striatus, Metynnis maculatus, R. quellen, Rhinodoras dorbignyi and $S$. nasutus. These species show greater abundance in distinct types of environments, in which the reproduction and feeding are more adjusted to rivers and small tributaries [24].

The diversity is higher on preserved sites with original fluvial characteristics, in which habitat heterogeneity and lotic stretches are found [25]. The indexes tend to decrease with the interference of damming activities [26]. Evenness promoted differences on the structure of fish assemblage. High values of diversity index are characteristics of transition areas (ecotone) between river and dam [24]. In this study, similar conditions in the stretches Lotic/Lower and Lentic/Upper of the Taquari River were found, indicating a transition area.

This fish diversity are related to differences on the physical and chemical characteristics between lotic and lentic sites that characterize the river/dam gradient. In the study was included the composition of surrounding, as variation of forest, agriculture, pastures and abandoned areas percentage influencing the composition of fish species.

On the lentic stretches the water is stable, with more deposition and accumulation of bottom sediment, prevailing silt and clay organic detritus in comparison with the lotic stretches. Additionally, the light penetration in water is higher than in lotic stretches and there is a greater concentration of chlorophyll$a$, due to the increase of phytoplankton. The electrical conductivity in dam is lower than in tributary (Taquari River) due to the decrease of ions concentration in the water by dilution.

Sites under strong anthropic influence provides greater fish assemblages homogenization and result in low diversity and high abundance of few species [27]. Activities such as agriculture, livestock and urbanization close to the riverbanks reduce the riparian vegetation, increase temperature, incidence of solar light, erosion [10], predators, organic allochthonous materials besides excluding reproduction sites and some food resources [28].

Allochthonous materials might be accumulated in manancials and stationed waters, where will suffer a long process of decomposition and be responsible for the increased rates of organic matter. There was dominance of $C$. modestus in these locals. This small sized opportunistic species feeds detritus and it occupies locals with deceleration of the water and thus high organic matter. It is the cascade effect reported for Agostinho et al. [29], which hinders the success of rheophilic species in downstream areas, reducing the species richness, the number of predators and the medium size of the species [29]. This suggests that C. modestus uses these environments to refuge and it has an important role in cycling of nutrients.

Piscivorous fishes or opportunistic tending to be piscivorous, like Hoplias malabaricus, Oligosarcus paranensis, P. maculatus, and $R$. quelen, are found in 
greater abundance in the river stretches (Lotic/Upper, Lotic/Lower and Lentic/Upper) while the preys A. altiparanae and A. fasciatus are found in the stretch Lentic/Lower. The importance of the different environments analyzed must be considered, since these may be used by several species in order to complete their life cycle [30]. Areas with varied habitat conditions receive more input, increasing the food resources available [31].

Therefore, this study demonstrated that upper stretches of this tributary (lotic) harbor the remaining fish fauna that is less susceptible to the consequences of damming. The presence of riparian forest and the conservation of tributaries considerably contribute to impacted fish diversity by dam. Information on this perspective makes the Taquari River a model to better understand the ecological dynamics and environmental management, considering that reservoirs have dozens of tributaries that may be exhibiting the same effect.

\section{Acknowledgements}

The authors thank Dr. Edmir Daniel Carvalho for the consolidation of the project involved; Dr. Langeani from Laboratório de Ictiologia, Departamento de Zoologia e Botânica da Universidade Estadual Paulista UNESP, campus de São José do Rio Preto, for identifying the morpho-types; and the $\mathrm{CNPq}$ and the FAPESP for financial support.

\section{References}

[1] Dray, S., Pélissier, R., Couteron, P., Fortin, M. J., Legendre, P., PeresNeto, P. R., ... \& Wagner, H. H., Community ecology in the age of multivariate multiscale spatial analysis. Ecological Monographs, 82(3), pp. 257-275, 2012.

[2] Agostinho, A. A. \& Gomes, L. C., Reservatório de Segredo: bases ecológicas para o manejo. Eduem, Maringá, 1997.

[3] Kovalenko, K., Thomaz, S. \& Warfe, D., Habitat complexity: approaches and future directions. Hydrobiologia, 685, pp. 1-17, 2012.

[4] Jackson, D. A., Somers, K. M. \& Harvey, H. H., Null models and fish communities: evidence of nonrandom patterns. American Naturalist, pp. 930-951, 1992.

[5] Oliveira, E. F., Minte-Vera, C. V., \& Goulart, E. Structure of fish assemblages along spatial gradients in a deep subtropical reservoir (Itaipu Reservoir, Brazil-Paraguay border). Environmental biology of fishes, 72(3), pp. 283-304, 2005.

[6] Cooney, P. B., \& Kwak, T. J., Spatial Extent and Dynamics of Dam Impacts on Tropical Island Freshwater Fish Assemblages. BioScience, 63(3), pp. 176-190, 2013.

[7] Vannote, R. L., Minshall, G. W., Cummins, K. W., Sedell, J. R., \& Cushing, C. E., The river continuum concept. Canadian journal of fisheries and aquatic sciences, 37(1), pp. 130-137, 1980. 
[8] Marques, M. M. \& Barbosa, F., Biological quality of waters from an impacted tropical watershed (middle Rio Doce basin, southeast Brazil), using benthic macroinvertebrate communities as an indicator. Hydrobiologia, 457, pp. 69-76, 2001.

[9] Murchie K., Hair, K., Pullen, C., Redpath, T., Stephens, H. \& Cooke, S., Fish response to modified flow regimes in regulated rivers: research methods, effects and opportunities. River Research and Applications, 24, pp. 197-217, 2008.

[10] Dias, A. M. \& Tejerina-Garro, F. L., Changes in the structure of fish assemblages in streams along an undisturbed-impacted gradient, upper Paraná River basin, Central Brazil. Neotropical Ichthyology, 8, pp. 587-598, 2010.

[11] Silva, A. M., Nalon, M. A., Kronka, F. J. N., Alvares, C. A. A., Camargo, P. B., \& Martinelli, L. A., Historical land-cover use in different slope and riparian buffer zones in watersheds of the State of São Paulo, Brazil. Scientia Agricola, 64(4), pp. 325-335, 2007.

[12] Gomiero, L. M., \& Braga, F. M. S., Ichthyofauna diversity in a protected area in the state of São Paulo, southeastern Brazil. Brazilian Journal of Biology, 66(1a), pp. 75-83, 2006.

[13] Carvalho, E. D., Ações Antrópicas e a biodiversidade de peixes: status da represa de Jurumirim (Alto Paranapanema). Tese de Livre docência. UNESP, Botucatu, São Paulo, 2009.

[14] Melo, A. S. \& Hepp, L. U., Ferramentas estatísticas para análise de dados provenientes de biomonitoramento. Oecologia Brasiliensis, 12(3), pp. 463-486, 2008.

[15] Henry, R., Santos, A. A. N. \& Camargo, Y. R., Transporte de sólidos suspensos, $\mathrm{N}$ e $\mathrm{P}$ total pelos Rios Paranapanema e Taquari e uma avaliação de sua exportação na Represa de Jurumirim (São Paulo, Brasil). In Henry, R. (Ed.). Ecologia de reservatórios: estrutura, função e aspectos sociais. FUNDIBIO/FAPESP, Botucatu, pp. 687-710, 1999.

[16] Luciano, S. C. \& Henry, R., Biomass of Eichhornia azurea Kunth. and Brachiaria arrecta Stent. in lower Taquari river, Jurumirim Reservoir, São Paulo, Brazil. Verhandlungen der Internationale Vereinigung für Theoretische und Angewandte Limnologie,26, pp. 1857-1861, 1998.

[17] Jorcin, A. \& Nogueira, M. G., Benthic macroinvertebrates in the Paranapanema reservoir cascade (southeast Brazil). Brazilian Journal of Biology, 68, pp. 1013-1024, 2008.

[18] Krebs, C.J., Ecological methodology. Harper \& Hall, New York, 1989.

[19] Oksanen, J., Kindt, R., Legendre, P., O’Hara, B., Stevens, M. H. H., Oksanen, M. J., \& Suggests, M. A. S. S., Package 'vegan'. Community ecology package, version, 2(9), 2013.

[20] Felipe, T. R. A. \& Suarez, Y. R.,Caracterização e influência dos fatores ambientais nas assembleias de peixes de riachos em duas microbacias urbanas, Alto Rio Paraná. Biota Neotropical, 10(2), pp. 143-151, 2010.

[21] Borcard, Daniel, François Gillet, \& Legendre, P., Numerical ecology with $R$. Springer Science \& Business Media, 2011. 
[22] Langeani, F., Castro, R. M. C., Oyakawa, O. T.,Shibatta, O. A., Pavanelli, C. S. \& Casatti, L., Diversidade da ictiofauna do Alto Rio Paraná: composição atual e perspectivas futuras. Biota Neotropica, 7(3), pp. 1-17, 2007.

[23] Carvalho, E. D., Silva, R. J. Ramos, I. P. Paes, J. V. K. Zanatta, A. S. Brandão, H. Zica, E. O. P. Nobile, A. B. Acosta, A. A. \& David, G. S., Ecological features of large neotropical reservoirs related to health of cage reared fish. In: Carvalho, E. D., Silva, R. J. \& David, G. S. (Eds.). Health and Environment in Aquaculture. Health and Environment in Aquaculture. INTECH Open Science, Rijeka, 2012.

[24] Carvalho, E. D., Silva, V. F. Fujihara, C. Y. Henry, R. \& Foresti, F., Diversity of fish species in the River Paranapanema-Jurumirim, Reservoir transition region (São Paulo, Brazil). Italian Journal of Zoology, 65, pp. 325-330, 1998.

[25] Agostinho, A. A., Pelicice, F. M. \& Gomes, L. C., Represamentos e a fauna de peixes neotropicais: impactos e manejo relacionados à diversidade e à pesca. Brazilian Journal of Biology, 68(4), pp. 1119-1132, 2008

[26] Pracheil, B. M., McIntyre, P. B. \& Lyons, J. D., Enhancing conservation of large-river biodiversity by accounting for tributaries. Frontiers in Ecology and the Environment, 11, pp. 124-128, 2013.

[27] Li, J., Dong, S., Peng, M., Yang, Z., Liu, S., Li, X. \& Zhao, C., Effects of damming on the biological integrity of fish assemblages in the middle Lancang-Mekong River basin. Ecological Indicators, 34, pp. 94-102, 2013

[28] Smith, W. S., Petrere-Jr, M. \& Barrella, W., The fish fauna in tropical rivers: the case of the Sorocaba river basin. Revista de Biologia Tropical, 51(3-4), pp. 769-782, 2003.

[29] Agostinho, A.A., Gomes, L.C. \& Pelicice, F.M., Ecologia e manejo de recursos pesqueiros em reservatórios do Brasil. Eduem, Maringá, 2007.

[30] Kipper, D. B. A. \& Santin, M., Composição taxonômica da assembleia de larvas de peixes no reservatório de Rosana, Rio Paranapanema, Brasil. Biota Neotropica, 11(1), pp. 421-426. 2011.

[31] Orsi, M. L., Carvalho, E. D. \& Foresti, F., Biologia populacional de Astyanax altiparanae Garutti \& Britski, 2000 (Teleostei, Characidae) do médio rio Paranapanema, Paraná, Brasil. Revista Brasileira de Zoologia, 21(2), pp. 207-218. 2004. 